Article

\title{
Social Economy as the Means to Help Achieve the Targets of Sustainable Development Goal 14
}

\author{
Sofia Arana Landin 1,2 \\ 1 Facultad de Derecho, University of the Basque Country (UPV/EHU), Paseo Manuel de Lardizabal s/n, \\ 20018 San Sebastián, Spain; sofia.arana@ehu.es \\ 2 Environmental Law Institute Visiting Scholar, 1730 M Street, Suite 700, Washington, DC 20036, USA
}

Received: 21 April 2020; Accepted: 21 May 2020; Published: 2 June 2020

\begin{abstract}
There are practical challenges for the implementation of the Sustainable Development Goals (SDGs) of the United Nations 2030 Agenda. In a number of policies, social economy (SE) entities can play a central role in terms of achieving their targets. One possible method of implementing several of the SDGs is through the promotion of such entities, as these have already proved to be a successful method for achieving different objectives related to a better quality of life and sustainability (i.e., the creation of jobs, reducing inequality, local investment, responsible social practices, or environmental protection). However, it is not immediately obvious that these entities can also help implement SDG 14, which aims to "conserve and sustainably use the oceans, seas and marine resources for sustainable development." The purpose of this paper is to empower sustainable small-scale fishing (SSF) through SE policies by means of a transdisciplinary approach. SSF is a sector that tends to be firmly rooted in local communities, with its traditions and values coinciding with those of the SE. Thus, SE entities can be an important asset to "Provide access for small-scale artisanal fishers to marine resources and markets." Therefore, different public policies in the area of SSF are proposed here in order to ensure they are implemented correctly.
\end{abstract}

Keywords: sustainable development; social economy; small scale fisheries; UN Agenda

\section{Introduction}

Undoubtedly, oceans form an essential part of our planet. According to United Nations (UN) data [1], they not only absorb $30 \%$ of the carbon dioxide produced by humans, reducing the impact of global warming, but even more crucially they provide fish, the world's largest source of protein, with more than three billion people depending on the oceans. As Jentoff, Chuenpagdee et al. state [2]: "Fish are one of the most internationally traded foods, and the value of global fish trade exceeds the value of international trade of all other animal proteins combined (World Bank, 2011)." This means that over three billion people depend on marine and coastal biodiversity for their lives.

The cumulative impact of human activities is stressing the earth's ecosystems. As Rockstöm et al. note [3]: "transgressing one boundary may, furthermore, seriously threaten the ability to stay within safe levels for other boundaries. This means that no boundary can be transgressed for long periods without jeopardizing the safe operating space for humanity." Human activities have already transgressed the ocean's boundaries, as there is a clear tendency towards deviation from the migratory patterns that have been followed for centuries and disease outbreaks that kill whole ecosystems, upending the communities that depend on them. Thus, our future has become an uncertain one, with exponential ocean warming and rising seas devastating coastal settlements, leaving communities that depend on the sea at risk [4]. For instance, in the Philippines, 10 out of 13 major fishing grounds are overfished. In Cantillan (Philippines), where there is no authority over the matter, everybody has been free to fish, resulting in overexploitation and a lack of fish for the coastal communities dependent on them. 
Even though these facts are reason enough to take care of the oceans, there are still more data, as shown by the UN 2030 Agenda, that highlight the importance of protecting our oceans for our own sustainability as a species. For all these reasons, effective marine resource management becomes critical to bringing ocean wealth back to those coastal communities.

As stated in the Technical Paper 2003 of the UN Food and Agriculture Organization (FAO) [5], in the late twentieth century they realized that there had to be some sort of control over the oceans. Meanwhile, there has been a process of division of resources among nations as a priority (through the establishment of sovereign rights) to ensure their conservation for the future. Chuenpagde et al. [2], based on (FAO, 2014; HLPE, 2014) data, estimate that SSF represent around half of global fish catches. Moreover, these data are even higher considering catches destined for direct human consumption. All these are sufficient reasons for the existence of a UN SDG aiming to protect the oceans. The SDG in question is 14, with particular targets focused on Small Scale Fishing (SSF). Particularly in developing countries, SSF makes an important contribution to nutrition, food security, sustainable livelihoods, and poverty alleviation. Bené adds how "recent research on poverty helps show how socio-institutional mechanisms governing people's access to fisheries resources, rather than the resources themselves, play such a critical role in vulnerability to poverty [6]" Thus, in the case of SDG 14, one of its targets is "to provide access for small-scale artisanal fishers to marine resources and markets." This target has been studied by different scholars such as biologists, environmental specialists, but it is "ultimately a governance issue of considerable complexity and urgency" according to Jentoft (2019) [7]. However, this issue has not been explored in relation to the Social Economy (SE)(10). The purpose of this paper is to study this relationship, as it has already been proved (as is demonstrated in this paper) that the attainment of several of the SDGs can be achieved by the proper use of SE entities. The SE is a central actor in the 2030 Agenda for Sustainable Development approved by the UN, as can be seen from various studies and experiences [8,9]. ( See, in particular, the report by the Spanish Business Confederation of Social Economy (CEPES), The contribution of the Spanish Social Economy to the SDGs. IV Report on the experience of Social Economy Companies in Development Cooperation 2017-2019, available at https:/www.cepes.es/noticias/596_social-economy-central-actor-2030-agendaunited-nations-contributing-sustainable-development-goals\&lng=en.) where, according to this report, in the last 20 years, its associative fabric has executed 160 cooperation projects in 46 countries. Thanks to this work by their SE entities, since 2014 the living conditions of at least 210,000 people and 27,000 families have been improved. The execution of these projects has involved the management of 73.6 million euros between 1998 and 2018, of which Social Economy organizations have co-financed 22\% (16.1 million euros). Also, the Spanish social economy has a strong specialization in cooperation projects aimed at creating employment and supporting the creation of enterprises by vulnerable groups (farmers and small producers, among others) and women, in order to increase their economic resources, improve their socioeconomic environment, and promote greater equality of opportunity.

Thus, SE has been particularly related to those SDGs that concern employment, particularly SDG 8However, there have already been different practical experiences as regards other SDGs which are not that obvious at first sight but are relevant here, such as SDG 1, the fight against poverty [10] (as for instance, the example of the RAIS Foundation is an SE entity which promotes social integration, developing programs and projects in Madrid specifically aimed at homeless people and immigrants at risk of social exclusion in line with a number of SDGs (the fight against poverty, employment and inclusive economic growth, gender equality, education or fight against inequalities); SDG 3, on health [11]( as in the case, for instance, of Espriu Foundation, this cooperative entity works intensively in the health field to guarantee a healthy life and promote the well-being of citizens, as required by SDG 3); SDG 11, in relation to sustainable cities; and SDG 13 [12]( by way of an example we find the experience of AERESS (Spanish Association of Recovery of Social and Solidarity Economy) is an SE entity composed of 40 entities dedicated to the reduction, reuse and recycling of waste, with the objective of facilitating the socio-labor insertion of people at risk of exclusion. The business fabric represented by AERESS has managed to avoid the emission of 106 thousand tons of CO2, which is 
equivalent to 51,000 cars removed from traffic in one day and 15 million trees absorbing CO2 in one day.) SE has also played an important part in taking action on the weather (For instance, we find the success story of Arroyo Bodonal, a housing cooperative of Tres Cantos, the first residential building in Spain with geothermal energy which eliminates the production of $\mathrm{CO} 2$ waste, thus responding to SDG 11 regarding sustainable cities and 13, action for the weather.)

Thus, SE entities can also contribute to the achievement of the above-mentioned target of SDG 14, as different legal forms belonging to the SE can be considered to be more than adequate for the purpose of marine resource management, even though there is still not much literature regarding this matter. Within the SE, particularly fishermen associations and cooperatives in the form of worker or sea cooperatives, as well as producer or consumer ones, are suited for success in bringing long-term financial and ecological stability to their ecosystems. Good examples of best practices can be found in some Spanish fishermen guilds such as the Fishermen Guild of Tarifa, who have devised Trazamare as an individual traceability system, or the Polvo das Rías Fishermen Guild, who ensure there is no overexploitation of octopus.

Most ocean management decisions have their basis in different economic interests, which are concerned with neither the sea nor these communities. According to art 7.1.2 of the FAO Code of Conduct for Responsible Fisheries [13] (hereafter the FAO's Code) [13], it is important to identify those who may have a legitimate interest in order to include them in the process of achieving sustainable fisheries. Moreover, art.7.2.2.c of the Code explicitly maintains that the measures taken-for instance, those providing for the interests of fishers, including those engaged in subsistence, small-scale and artisanal fishers-are considered.

Thus, the enactment of a Social Economy Act (as has been passed in several countries, such as Spain, Portugal, or Italy), which can be later used as a framework for Marine Planning, seems a logical and natural approach that can facilitate posterior public policies in marine coastal management.

The ideal situation to achieve this SDG as regards this target would be to pass such an Act and then promote the possible entities that, acting within this framework, can help achieve the target of access for small-scale artisan fishers to marine resources and markets. For example, to provide for "community-based fisheries," the legal framework should set, among other requirements, specific obligations regarding the creation of co-management institutions, the organization of their meetings, and transparent participation and voting rules, as has been done by various SE entities for decades, so their expertise can be an asset to help achieve this proposed target.

\section{The Reality of Small-Scale Fisheries and Their Possible Relationship with Social Economy Entities}

The FAO Voluntary Guidelines for Securing Small Scale Fisheries [14] (hereafter the FAO's Voluntary Guidelines), following the FAO Code of Conduct for Responsible Fisheries [13], constitutes the first internationally agreed instrument as regards Small Scale Fisheries in the context of poverty eradication and food security. It is important to highlight that these guidelines deal mostly with the rights of fishers and fish workers, so they are concerned with the people that depend on the fish, not just the fish themselves. The effect of sociology, political economy, and anthropology on the development of aquaculture has already been studied [15] by different authors. However, this particular target has not been examined in relation to SE. There are many commonalities when SSF and SE entities are compared, and the purpose of this paper is to study both and make these connections, considering SE entities as a valid instrument for the promotion of SSF.

As stated in the FAO's Voluntary Guidelines, SSF constitutes a deeply rooted sector in the local communities which can be considered as sharing a common aspect with SE entities, as they are also generally interdependent on their communities. Another important aspect of SSF is the importance of both human rights vulnerable and marginalized groups, a trait that is also shared by SE entities. Again, Sustainable Social and Economic Development for the benefit of current and future generations is promoted in the FAO's Voluntary Guidelines, which can be regarded as another common link with SE. 
As described in the FAO's Voluntary Guidelines, many SSF workers are self-employed and engaged in directly providing food for their household and communities. Therefore, they are mostly characterized as "subsistence" fishers, so they do not fully realize their potential. Because of the drastic decline in fish, fishing is increasingly difficult, meaning that fishermen must go farther out in the sea to do it. Together with, among other impacts, the adverse effects of tourism in coastal communities, it is increasingly difficult for these fishermen to cater for themselves and their families.

The reality reported in the FAO's Voluntary Guidelines is worse than we could imagine, as SSF communities are commonly located in remote areas and tend to have limited or disadvantaged access to markets, and may have poor access to health, education, and other social services. In addition, there is also frequent illness, with above-average incidence of HIV/AIDS and inadequate organizational structures [14].

Thus, as we have seen, at a time of overexploitation of resources and threats to habitats and ecosystems, the promotion of SSF presents numerous challenges. Their co-management in SE entities needs to replace non-participatory and often centralized fisheries management systems. Moreover, as noted by Chuenpagdee [2], SSF communities also commonly suffer from unequal power relations. In many places, conflicts with large-scale fishing operations are an issue, and there is increasingly high interdependence or competition between SSF and other sectors. These other sectors usually have stronger political or economic influence (i.e., tourism, agriculture, energy, industry, and infrastructure developments) [14].

In this context, the available opportunities are obviously very limited. However, it should be borne in mind that this is precisely the context in which different forms of SE entities tend to flourish, as has occurred throughout the last few centuries. SE entities such as associations and cooperatives have a role in promoting structural and long-term reform, and have extensive experience in providing innovative responses to economic and social needs along with a solid structure based on values and principles. Moreover, these values and principles have proved to be the correct ones, providing stability to these entities during the previous economic crisis. Thus, SE entities are of great importance for improving the living and working conditions of people in SSF as well as making essential infrastructure and services available even or mostly in areas neglected by the state and investor-driven enterprises.

For instance, values at the heart of the SE movement are central to creating decent jobs. They also play an increasingly important role in balancing economic, social, and environmental concerns as well as contributing to poverty prevention and reduction. Thus, cooperation brings fresh air to inspire small-scale and artisanal fishing: SE entities have been emphasizing corporate social responsibility for nearly two centuries before it was discovered as such [16], through greater responsibility, solidarity, and equity: solid pillars for a society with more cohesive and solid values.

Although cooperation as a form of individual and societal behaviour can be considered to be intrinsic to every human organization, the history of modern cooperativism finds its roots in the agricultural and industrial revolutions. These roots can be traced to multiple influences (for instance cooperative networks of Ampekalia in Greece at the end of the 18th century) However, one of the most important can be found in the United Kingdom in the nineteenth century. A rejection of the so called "Poor Laws" in 1834 gave way to Friendly Societies, which can be said to share common values with cooperatives. At the time, as certain institutions began to routinely distinguish between the 'deserving' and 'undeserving' poor, a movement of Friendly Societies grew throughout Britain based on the principle of mutuality, committed to self-help in the welfare of working people. Friendly Societies established forums through which the philosophy of one-member, one-vote was practiced in organisation decision-making. The principles challenged the idea that every person should be an owner of property.

Pollution, environmental degradation, climate change impacts and natural and human-induced disasters add to the threats facing SSF communities. All these factors make it difficult for small-scale fishers and fish workers to make their voices heard, defend their human rights and tenure rights, and secure the sustainable use of the fishery resources on which they depend [14]. However, 
whenever fishermen/women join forces, constituting an SE entity, they can better achieve their goals and fully realize their potential, improving not only their socioeconomic situation but also that of their communities. For this purpose, SE entities, devoted to fishing and all its possible related activities, can provide jobs in commercial fishing, processing, and marketing, contributing to social and economic cohesion and community economic development. Thus, they can contribute to a more sustainable future, helping to achieve some of the targets of SDG 14, as well as many other SDG, by the use of these entities.

Following the FAO Voluntary Guidelines, States should facilitate, train, and support SSF communities to participate in and take responsibility for (considering their legitimate tenure rights and systems) the management of the resources on which they depend for their well-being. Accordingly, States should involve all parties in SSF communities-with special attention to the participation of women and vulnerable groups such as minorities-in the design, planning, and, as appropriate, implementation of management measures, including protected areas, which affect their livelihood options. Participatory management systems, such as SE entities, should be promoted in accordance with national law [14], so that such entities become the ideal tool to achieve these goals.

\section{An Approach toward the Social Economy for Small-Scale Fishing}

Even though it is clear that cooperatives, as the centerpiece of SE, can help a coastal community, there may be other legal types that can also be useful for the achievement of these communities' targets. Thus, according to the most advanced SE laws, there are other sort of entities, apart from cooperatives, that can be useful to achieve this aim. For instance, at first glance, the following SE entities can be important for this target: fishermen guilds, associations, and foundations.

Fishermen guilds refers to public law sectoral non-profit enterprises representing the economic interests of the ship owners of fishing vessels and the workers in the extractive industry. They act as consultative and collaboration bodies for the administrations with competences in sea fisheries and the regulation of the fisheries industry, and aim to satisfy the needs and interests of their members, with a commitment to contributing to local development, social cohesion, and sustainability. Thus, they can be regarded as a valid interlocutor for coastal management plans.

Associations provide services where the offer of the for-profit sector fails. They are usually linked to industries covering fundamental rights, especially as regards accessing vulnerable collectives, such as subsistence or artisanal fishermen, ethnic minorities, or women. Thus, they can better defend the rights of the people associated, based on the respect of diversity, plurality and tolerance, and should also be listened to and promoted as regards coastal management.

Foundations are non-profit organizations whose assets are conditioned to carrying out an objective goal of general interest by the will of their creators. The aim to "provide access for small-scale artisanal fishers to marine resources and markets" is of general interest for the community, so foundations can also benefit from public policies of promotion in this area.

This kind entity can be of great assistance to fish workers by joining forces with them, so they can therefore be considered as an asset for coastal management.

The first question Lam and Pauly asked themselves in this "To protect living fish, while also benefiting from the capture of wild fish, new legislation and governance mechanisms are needed to enable society to exercise its collective right and moral responsibility to minimize further ecological damage. The global community has the power to vote in governments that will enact laws and design regulatory incentive structures to protect fish and society; it must also share the responsibility of determining what is acceptable for the present and desirable for future generations. The matter [17] is still pertinent as regards this paper's aim: who has the right to fish? They answer as follows: "Shifting societal baselines to redefine a dynamic social contract for ethical fisheries is thus a collective choice in which all citizens have a stake, and indeed, a right."

Thus, governments, based on these demands, need to ensure regulations and governance mechanisms to protect fish for future generations. Therefore, following a bottom up decision-making 
process, the right to fish must be carefully regulated. It is here, this paper argues, where SE entities are of the upmost importance; because they follow the general interest, they are bound to act ethically and protect the general interest of future generations, and so they need to be registered and have surveillance and control over their members.

\section{The Question of the Substance and form of Social Economy Entities}

We must ask ourselves where the line can be drawn as regards SE entities for SSF that can be of use. The questions that should be asked, in order to help coastal management, are as follows: should there be a closed given list of legal forms that form part of the SE and that can benefit from the possible public policies towards those communities? Should there be an open list? Should there be no list at all? Should there be a register? Should it be closed, only for nonprofit? Or should it include for-profit entities?

In the philosophical writings of Cornforth [18], he states that the forms of things always become evident before their substance. Thus, form and substance must have an adequate correlation. In our case, we tend to assume that entities with a given form may be part of the SE, whereas others with a different legal form cannot. For instance, we all assume that a cooperative is going to form part of the SE, whereas a Limited Liability Company will not. However, the concept we have of cooperatives is not a "one size fits all" concept. In some countries, cooperatives have constrained property rights (both alienation and accumulation constraints (as, for instance, in Italy or Spain there are very important alienation and accumulation constraints having a substantive law where there is a list of causes of withdrawal of the fiscal protection in the cases where these constraints are not respected.), whereas in others, they do not. For instance, worker cooperatives in the USA, where there is no clear and comprehensive regulatory framework for worker cooperatives. In my opinion, this may be one of the main causes for the scarcity of worker cooperatives in this country. Thus, tax laws divide businesses into categories and worker cooperatives try to fit into the recognized forms of business but "acting on a cooperative basis" wihout having the alienation and accumulation constraints there should be in order to achieve their purpose (see subchapter S IRC).

In some countries, there are important limits to their operations with third parties. For instance, agricultural cooperatives in Spain are restrained from dealing with third parties over a 50\% of their operations, whereas in others there are no limits at all. In some countries, cooperatives must be registered (as, for instance in France, Italy, or Spain where in order to be considered a cooperative they need to have been constituted and registered as such (see 20/1990 Spanish Act on Cooperatives), and their social, economic, and environmental contribution to their community economic development may be measured, whereas in others they are not even registered, which poses enormous difficulties towards measuring their effective contribution. A success story of the benefits of this control is the case of satellite accounts in Spain from 2008, presented in 2011, following the CIRIEC, Manual para la elaboración de las cuentas satélite de las empresas de Economía Social: cooperativas y Mutuas. Hereafter, satellite accounts have been measured in Spain. More recently, Mexico, has published its SE satellite accounts.

Cooperatives are probably the best exponent of the SE, as they are the basis of it. They not only contribute to the attainment of the commitment made by Goal 8 of the 2030 UN Agenda, to promote "sustained, inclusive and sustainable economic growth, full and productive employment and decent work for all," but they can also be a valuable instrument to achieve many other goals. Among the agreed UN SDGs, the following can be better achieved through cooperatives: ending poverty, achieving gender equality, quality education and lifelong learning, health, food security and good nutrition, access to water and sanitation, sustainable energy, employment creation, livelihoods and equitable growth, sustainable natural resource management, good governance, the promotion of stable and peaceful societies, and global enabling environment and long-term finance (ILO/ICA 2016).

Cooperatives do not act like normal corporations; for this reason, they are usually subject to different public policies such as tax laws, which cannot be considered to be a "benefit," but rather 
represent an understanding of their differences and a fair compensation. However, if we considered that only workers of marine cooperatives were to achieve the benefits of public policies for SSF, we would most likely be mistaken.

There is no common definition of what cooperatives are, so in order to ensure their visibility and promote them through reasonable and fair policies, we need to ensure they comply with minimum principles. If cooperatives are to be promoted for SSF purposes, a common consensus of what they are must be established beforehand.

\section{An Example of the Problem Limiting the Scope}

The fact that there is no common and universal "fit for all" definition of what the form of cooperatives really is may present a problem, as it harms the entities that do act on a cooperative basis. As Gutnecht points out [19]: "allowing something that is not a cooperative to call itself a cooperative squanders a precious asset - the goodwill and public trust that reposes in the word 'cooperative'."

Thus, the fact that in different countries there is a different understanding of what a cooperative really means may be judged in different ways: first, entities which are not cooperatives in their true essence, in their substance, can benefit from the associations people make towards cooperatives in general, which does not appear fair. Thus, a set of minimum requisites must be established beforehand. Second, the fact that there is no universal common understanding of what being a cooperative truly means is not an insurmountable obstacle, as the entity may be adapted to the peculiar needs and situation of the community.

Thus, even though there is a global understanding of what cooperatives are, in practice, their features and regulation vary from country to country to the point where, in some countries, the legal form is not a regulated choice, so they may not be able to profit from their advantages to the full extent. This is why, in order to use this SE form to implement the target "to provide access for small-scale artisanal fishers to marine resources and markets" there is a need to assess the needs a particular community has, checking not only whether the cooperative form exists or not but also the way in which it does exist. This ensures that, in practice, form and substance coincide. If the form exists, it must still follow several principles:

- Persons and the social objective take precedence over capital. This means that decision-making should prioritize people, and their contribution to the work and services offered by the institution or the social objective, over equity capital;

- Profits are mainly distributed based on the work contributed or the service or activity carried out by its partners or members with respect to the social objective of the institution;

- Fostering internal and social solidarity, promoting commitment to local development, equal opportunities for men and women, social cohesion, the integration of persons at risk of exclusion, generating stable and quality employment, work-life balance, and sustainability;

- Independence from public authorities.

Thus, in most countries, cooperatives follow these principles and are able to contribute to community economic development, so these entities may be beneficiaries of marine coastal planning. However, there may be instances where the cooperative form does not really follow these principles or instances or where it does not exist as such. Moreover, there may be cases when other kinds of legal forms may follow the aforesaid principles. All this means that form is not as importance as substance, and we should refrain from making closed lists of legal forms that may misguide us. What should be important is to register the entities that follow these principles, contribute to community economic development, and may benefit from marine coastal planning.

In countries with an important SE sector, such as Spain, the Social Economy Act (hereafter the SE Act) creates a legal framework that does not aim to replace the current law for each of the different entities in the sector, but rather recognizes and gives greater visibility to the SE by giving it greater legal security through actions to define it. Thus, the SE Act establishes the principles to adhere to 
by the different entities that are part of it. This way, in the case of coastal management, and unlike previous public policies concerning SSF, implementing an act for SE entities that serves as a framework so that public policies are directed toward this kind entity can be a first step to achieving the target of SDG 14 .

The SE Act should be based on common principles, thus it should include not only all the different entities and enterprises that make up the SE but also any other entity with corporate social responsibility that is based on those principles. As many enterprises could share the guiding principles of the SE, setting a clear framework not only with the principles, but also, with a register, helps keep possible fake entities at bay and also facilitates dialogue, participation and, above all, implementation. Thus, cooperative societies in their various forms, among them, those organized on the basis of pooled work (consumption, housing, agriculture, services, maritime work, credit, education, health, and transport insurance); labor societies; associations; foundations; mutual societies; special employment agencies; special employment centers; agricultural production societies; and fishermen's associations can be considered to be specific SE entities. Among these, cooperatives (particularly maritime work ones, worker, producer, consumption cooperatives), labor societies, and associations, particularly fishermen guilds, associations, and foundations, can be considered the most important for the purposes of this paper.

However, other forms of SE entities, such as credit cooperatives, can also become very useful as a complement, for instance as regards micro-credits. This is an important instrument, as one of the policies to be taken could involve making micro-credits available. Thus, what is important is that other sort of entities, if they follow the SE principles, could be considered to be SE, as most of the SE Acts set forth, if they follow the following principles:

- Persons take precedence over capital. This means that decision-making should prioritize people and their contribution to the work and services offered by the institution or the social objective over equity capital;

- The notions of the person, the team, participation, responsibility taking, equitable sharing, and democratic management are fundamental. Members apply values that are universally recognized with the goal of doing business that is centered on the person and not the profit. This is because far more important than profits are people, who voluntarily adhere to this economic and social development ideal for the satisfaction of exceeding their goals and being open to others. However, this does not mean, as is made clear by the following point, that these entities must be non-profit. For the purpose of benefitting people working in SSF, we cannot limit them;

- Profits are mainly distributed based on the work contributed or the service or activity performed by its partners or members as regards the social objective of the institution. Even for artisan or small-scale fisheries, there is no problem in them being "for profit." There is no point in reducing their scope to subsistence and not letting them grow, as long as they remain small scale.

Another question is concerned with the definition of what can be considered "small-scale." Even though there is no common accepted definition by the FAO, there are several features that may define what can be considered SSF in terms of our target. For instance, it tends to be near the coast, using small vessels, making short trips, artisanal, involving fishing households (as opposed to commercial companies), using a relatively small amount of capital and energy, relatively small fishing vessels (if any), and mainly for local consumption.

Chuenpagdee [20] adds, in the context of fisheries, "The majority of the world's fisheries comprise small-scale, multi-species, multi-gear, commercial fishing vessels, operating in all bodies of water (inland, brackish and marine), both near urban centers and in remote areas. Their operation involves family members, in pre-harvest, harvest and post-harvest parts of the fish chain. Women and children often participate in the fisheries. Small-scale fisheries catches are landed relatively close to where fishing occurs and are distributed through various channels. A certain portion is generally sold to local markets or to intermediaries by family members and some remains for household consumption. 
These characteristics of the fisheries imply that they require different management approaches than large-scale, industrialized fisheries". that management efforts also need to consider how the legitimacy of rules and regulations may be perceived differently when applied to large- versus small-scale, as their different inherent characteristics meant that they require different management approaches.

According to UN data, as at least half of the world's fish population catches are derived from SSF, success in fishery management needs to be demonstrated not only where large-scale fisheries dominate, but also in the small-scale sector, with its high potential for addressing global food security. Any entity adhering to the following principles:

- Fostering internal and social solidarity, promoting a commitment with local development, equal opportunities for men and women, social cohesion, the integration of persons at risk of exclusion, generating stable and quality employment, work-life balance and sustainability;

- Independence from the public authorities.

can be said to belong to the SE, so it is important for coastal management to identify and register these SE entities to make them subjects of certain public policies, in order to facilitate what Jentoff calls "interactive governance" [7].

The question of whether the entities need to be non-profit is not really a relevant one. For instance, different forms of SE entities may be considered to be for-profit in one country and non-profit in another. Limiting their profitability should not be a target, as long as they remain small-scale.

\section{Policies That Promote Small-Scale Fishing Social Economy Entities}

In accordance with Weiner [21], public policy can be defined as follows "the course of action or inaction taken by government with regard to a particular issue or set of issues." The concept of public policy [22] thus encompasses that of social policy, sharing most of its characteristics. However, the concept of the former is broader than that of the latter, including such policy areas as educational, agricultural, local and industrial development, environmental, etc. Thus, such policies can involve the intervention of the state, regional, or local public authorities.

To begin with, for SSF policies it is important to know the distribution of competences in the particular coastal area in order to ascertain that all the authorities concerned can organize around these policies. The main purpose of the intervention is to protect the general interest, bearing in mind the FAO's different regulations and guidelines in this matter. Taking due account of Art. 6.18 of the Code, states should, where appropriate, grant small-scale fisheries preferential access to fish in waters under national jurisdiction. This intervention may take a large variety of forms, including legislation, policy statements, white papers, social and fiscal measures. Without state intervention, there is no public policy. Notwithstanding, by relying solely on state, regional or local intervention, it is difficult to secure quality social and public policy. In this section, an attempt is made to seek the best public policies for SE entities in the context of SSF.

Shaping public policy is a very complex process that sometimes not only involves the state, regional, or local authorities but also the interplay of numerous individuals and interest groups competing and collaborating to influence policymakers to act in a particular manner. Interest groups use a variety of tactics achieve their goals, including advocating their positions publicly, attempting to mobilize allies on a particular issue and trying to influence decisions. In the case of SSF, when considering public policies it is important to emphasize a bottom-up participatory development process so that all possible interlocutors in the coastal community are consulted, particularly the most vulnerable who may not have as much influence with policy makers, while still considering the FAO's Voluntary Guidelines.

As Lam and Pauli note [17]: “Only with responsible fisheries management and governance, through transparent, accessible, and accurate information, costs, and benefits, will the public become vested and responsible resource owners and stewards." Once the consultation process is finished, all sorts of possible costs and benefits (social, environmental, financial) must considered in relation to 
that particular coastal community, respecting their particular culture and, most particularly, following the UN Declaration on the Rights of Indigenous Peoples, including indigenous people or minorities [23] if this is required. Thus, in certain cases, the UN Declaration on the Rights of Indigenous Peoples (UN DRIP) needs to be considered in the whole decision-making process related to fishery resources and areas where small-scale fisheries operate as well as adjacent land areas, and also considering existing power imbalances between different parties.

Another important aspect that must be tackled is the encouragement of women leadership, in accordance with Art. 5 of the Convention on the Elimination of All Forms of Discrimination Against Women (CEDAW). As Art. 5 CEDAW says that "States Parties shall take all appropriate measures in order to modify the social and cultural patterns of conduct, with a view to achieving the elimination of prejudices and customary and all other practices which are based on the idea of the inferiority or the superiority of either of the sexes or on stereotyped roles for men and women. Also they shall take adequate measures to ensure that family education includes a proper understanding of maternity as a social function and the recognition of the common responsibility of men and women in the upbringing and development of their children, it being understood that the interest of the children is the primordial consideration in all case."

SE entities in the coastal community also need to be consulted, as they contribute to solving socially important and general interest problems. In general, SE entities make a real contribution to economic growth but also ensure fairer income, a social conscience, and wealth distribution. Thus, SE entities therefore reduce the effort public policy makers must make to achieve their goals, and should take a leading role in public policy making. They already play an important role in society; therefore, all that is required is that their importance be acknowledged to achieve a common goal. They have a very long tradition of acting with great credibility to achieve social interests, so policymakers should be encouraged to trust them and even seek out their advice. In summary, co-operation with SE entities is a natural step to take.

To achieve this aim, there is a need to involve both the community and the government (or competent territory) because they are the only ones that can understand and judge if the relevant principles are being followed, as well as the kind of policies that may be most needed, adapted to their own situation and the needs in that given community. Once we have the relevant information in this respect, there is also the need to know how laws, policies, and institutions operate in practice, in order to assess which public policies of promotion might be the most suitable for that particular community. Such communities should be involved in the decision-making processes and management of small-scale fisheries, so as to ensure responsible fishing practices and the sustainable use of fishing resources. However, it must not be forgotten that public policies concerning them cannot be used for entities that do not respect minimum principles, in order to avoid other interests profiting from and gaining a share of coastal communities. For this purpose, setting minimum standards that protect real SE entities from the ones that could be considered to be so only "on paper" becomes a priority.

\section{Particular Policies in the Context of Small-Scale Fishing}

As for the public policies, they can have different forms: to those we can find in the FAO's Voluntary Guidelines (for instance, giving tenure rights to SSF entities, creating exclusive zones or implementing marine spatial planning) we could add other sort of policies that can be found in the context of SE, such as tax or labor policies.

To begin with, particular attention should be given to the dissemination of the SE so that people involved in the process know how to create, register, and maintain a SE entity that, through this co-management formula, will later be an active part of the process. This helps both the interests of the fish workers, who will have a stronger and united force, and public institutions (because reaching agreements and control is also easier through the representation of these entities). Microcredits for this purpose or very limited costs are essential.

Marine Spatial Planning (MSP), being the public process of analyzing and allocating the spatial and temporal distribution of human activities in marine areas to achieve ecological, economic, 
and social objectives that are usually specified through a political process Douvere and Ehler [24], is a key instrument regarding the promotion of this target. MSP is linked to ecosystem-based management (see McLeod and Leslie [20]).

Within MSP, the FAO's approach to the matter needs to be considered, not only as regards the Code (1995) and the Voluntary Guidelines, but also the FAO's Ecosystem Approach to Fisheries [5] It should be borne in mind that EAF is a general approach to fisheries management that essentially balances the aims for human and ecological well-being under the broad concept of sustainable development in a fisheries context. The broad data and information base required for implementing the EAF incorporates scientific, traditional and local knowledge of fisheries resources, the ecosystem, and the socioeconomic context. (FAO 2015).

(EAF) (see FAO EAF 2003 and FAO EAF 2015) and marine protected areas (MPAs) (FAO report on MPAs and Fisheries, 2011). Local ecological knowledge [16] is also a great asset that should be kept in mind. All these documents help us in managing conflicts through participation among diverse stakeholders, such as large-scale fishing and other sectors such as tourism, who may have competing interests. The fact that the valid interlocutors are not individuals but SE entities that strive towards the common interests of their members makes the process easier, despite its difficulties. In this way, it is easier to have well-organized representation in relevant local, regional, or national professional associations and fisheries bodies who actively take part in relevant decision-making and fisheries' policy-making processes.

It should be remembered that many SSF SE entities are directly dependent on access to fishery resources and land. Thus, tenure rights to land in the coastal/waterfront area are critical for ensuring and facilitating access to the fishery, for accessory activities (including processing and marketing), and for housing and other livelihood support. The health of aquatic ecosystems and associated biodiversity is a fundamental basis for their livelihoods and for the subsector's capacity to contribute to overall well-being [25].

The securing of tenure rights needs to be the base of SSF policies, as the different SE entities need to have access to SSF areas and adjacent land. Thus, a first step is to identify the legitimate tenure right holders and their rights. This can be a very important source of conflict, as customary law may not always correspond to different local or regional norms. The result must be consistent with all UN law, not only as regards human rights, but also ethnic minorities, women, SSF, etc. For the purpose of securing vulnerable groups, it may be appropriate to create exclusive zones. As regards women, their presence in fish vessels is unusual, so even though they are frequently dependent on fish as they deal with the nets, cleaning, processing, marketing, etc., they are sometimes not considered to qualify as fish workers, which poses a problem to be dealt with.

Following the bottom up process, SSF entities should be listened to, before possible agreements on resource access are reached with adjacent countries.

Before giving these tenure rights, the public authorities need to ensure that there is a strong commitment on the part of the different SE entities regarding both environmental and social matters so that the fish stock does not disappear for future generations. Registration should be compulsory, and a written commitment needs to be signed. As Lam and Pauly state [17]: "legal rights must be coupled with moral responsibilities if governments, private fishing enterprises and civil society are to conserve marine resources for present and future generations." This commitment needs to be made prior to any policy so that it can help future enforcement. Thus, public authorities need to ensure that they have a way of controlling the real performance of these entities in accordance with their commitment. Thus, a procedure of verification of their performance and the fact that the SE entities can temporarily lose their right to a given public policy, i.e., tenure rights, in the worst sanctioning cases, should be made clear in advance.

As part of their social commitment, an effort towards social security protection needs to be made. For this purpose, in the case where there is a public social security system, a social public policy may be made regarding a preferential regime or reduced rates, either temporarily or permanently. 
Another potential public policy to be considered, wherever possible, is access to microcredits or financial facilities, particularly to newly created entities. In this sense, we must remember that SE entities are assuming social and general interest issues that reduce costs for public administrations. It is, therefore, only fair that such incentives should be considered.

Moreover, if these SE entities work as such and are able to make profits, tax benefits (in either the form of reduced rates or tax rebates to promote reserves) could be temporarily or permanently offered to them. In this sense, the resilience of these entities can be reinforced by the compulsory allocation to reserves that give a right for those tax rebates. This way, the SE entity may be better prepared for a rainy day.

Ensuring good effective governance in SSF should include not only their protection, but their real control, as laissez-faire policies result in a clear diminished stock and overexploitation.

There must be a local experienced leadership, capable of understanding and promoting the technical advances in SSF, and of connecting with indirect activities for processing and marketing. It should be born in mind that it is in these indirect activities where women have a leading role. As women's presence in vessels is still rare, they engage themselves in fish production, processing and the marketing of fish products.

Finally, there must be a method by which the agreement can be withdrawn in cases where it is not respected. For this purpose, authorities must ensure that the SE entities understand that all possible public policies can be withdrawn not only in the cases where the agreement is not respected, but also in cases where new scientific data recommend doing so, (i.e., in the case of overfishing).

Local cooperatives in Japan responsible for the management of all fish activities can be considered to be a success story in terms of the sustainability and profitability of SSF. The Japanese system based on sea cooperatives has, in the long run, resulted in better care of the environment and better standards, which have contributed to the maintenance of the fish stock. These cooperatives have extensive experience in management, processing, price fixing, adapting to new technologies, and value-added processing. They have contributed to the safety of fishing vessels and improved the living conditions of current and previous generations and, most probably, generations to come.

Last, but not least, there may be communities whose dependence on fishing needs to diminish, as, for instance, in severe cases of overexploitation. In these instances, it is vital to introduce elements of territorial cohesion while supporting projects for coastal communities that are not strictly dependent on fishing. There have been some experiences in this direction led by the PESCA and LEADER initiatives in the EU [26]. These initiatives may be an important complement to the local economy [27].

As Small-Scale Fisheries play a very important role throughout the world, the EU has adopted special programs that can be considered as success stories, particularly in the cases of the Mediterranean and the Black Sea, where SSF add an important value to their local economies. In these cases, there usually are family-based fisheries where the owners are also workers. The best-known case of worker owners is precisely the cooperative form, where members lead both roles. Thus, in the case of the EU, the European Maritime and Fisheries Fund gives them financial support in order to promote their active role in economic, environmental, cultural and social projects at a local level. These policies help strengthen Community Economic Development in these areas. Of particular importance within them is the Regional Plan of Action for Sustainable Small-Scale Fisheries, both for the Mediterranean and Black sea coastal areas, adopted in 2018 that means a 10-year pledge in order to save Mediterranean fish stocks.

Even though the EU case can be taken as a good reference and model of what can be done, in the vast majority of cases of the developing world, the goal needs to be lowered. For instance, in the EU programs, there is even a $100 \%$ public aids and funding schemes for local projects such as engine replacements, low-impact techniques, fleet upgrades, fishing gear, acquisition of second hand vessels by the future generations, modernization tools, etc. However, this is usually not the case of many developing countries where the funding cannot reach these expectations and there is usually not such a need to seek young people who want to make a living out of the sea. 
Of particular relevance, among Fishing Local Action Groups, is the case of Greece, very recently commented by Kyvelou and Ierapetritis [28]. In the Greek success story, "it was used to help identify the potentials and challenges of the coexistence of small-scale fisheries and tourism, as perceived by a series of stakeholders including the co-management schemes".

Whenever a community is too dependent on harvesting and their situation is critical, reducing the harvesting activity in favor of other activities related to the sea, such as fish-tourism, craft goods, gastronomic tours or leisure activities, by creating and promoting a SE entity, may be a way out of their problem. The "FLAGs" or Fishers Local Action Groups in the EU have had a positive experience in this sense.

If this solution is not a feasible one, then training and vocational education in order to find jobs outside the fishing sector should also be encouraged. In the meantime, the fish stock may start recovering from overexploitation.

\section{Conclusions}

SSF are of an outstanding importance in order to maintain fish stocks and protect ecological and economic wealth in coastal areas, ensuring sustainability in the long term. There are too many people whose livelihoods, directly or indirectly, depend on SSF. Thus, there needs to be a clear support on the part of public administrations towards SSF.

There needs to be a proper management of the existing fish stocks and the people fishing them and this can be an insurmountable task, unless they are constituted as SE entities.

In order to help support SSF, adequate public policies need to be adopted. However, this is a most challenging task. Thus, SE entities can greatly help marine coastal planning, making fish workers join forces, ensuring the respect and compliance of all-important matters regarding the protection of SSF, in particular communities, reducing the number of interlocutors, and facilitating a dialogue with the competent public authorities.

Efforts must be made in order to disseminate the SE, ensuring that all voices are heard in the process, and all legislation and recommendations are followed, particularly regarding minority groups and women, leaving no one behind.

There needs not be a particular closed list of SE entities as regards the form, but rather an effort to ensure that all forms respect certain principles, in terms of both the legitimacy of the SE entity as such and in terms of SSF practices, following the FAO's guidelines.

There must also be guidance through the constitution process, either free or with minimum costs for the interested parties. Microcredits have the potential to become an important instrument, whenever the constituting and registration process of the SE also involves compulsory contributions.

A register of these entities is important, as is a written agreement that acts as a binding contract between the competent public authorities and the SE entities to ensure that whatever rights they get can be withdrawn in cases where the agreement is violated or there is a significant change in circumstances. This should preferably on a temporary basis, as a way to enforce compliance.

Public policies of promotion need to respect the FAO's regulations and recommendations. Among these policies, tenure rights and the establishment of exclusive zones can be of particular importance. Social and tax measures may also be of importance, particularly as regards their inclusion in a Social Security system and safety measures, whenever possible, as well as the promotion of the reinforcement of reserves. However, in certain cases, for instance in cases of overexploitation, for small-scale fisheries to be able to reach sustainability, there needs to be a promotion of other possible marine activities, as has been done in FLAG groups, particularly in the Mediterranean. Creating SE entities that devote themselves to complementary sea activities can boost community economic development of coastal areas, and, in the meantime, the stock may recover. 
Funding: This research was funded by the University of the Basque Country GIU 18/147 Research group and MINECO DER2015-63533-C1.

Acknowledgments: I hereby thank the Environmental Law Institute, in the person of Xiao Recio-Blanco, Director of Ocean Studies, for getting me interested in this matter and the University in the Basque Country for financing this research.

Conflicts of Interest: The author declares no conflict of interest.

\section{References}

1. UN General Assembly. UN 2030 Agenda, SDG n.14. In UN 2030 Agenda; UN General Assembly: Geneva, Switzerland, 2015.

2. Chuenpagdee, C.R.; McConney, P.; Munro, G.; Ferreira, B.; Marschoff, E.; Rice, J.; Rosenberg, A. Social and Economic Aspects of Sea-Based Food and Fisheries. In The First Global Integrated Marine Assessment; Inniss, L., Simcock, A., Eds.; United Nations: New York, NY, USA, 2016.

3. Rockström, J.; Steffen, W.; Noone, K.; Persson, Å.; Chapin, F.S., III; Lambin, E.; Lenton, T.M.; Scheffer, M.; Folke, C.; Schellnhuber, H.J.; et al. Planetary Boundaries: Exploring the Safe Operating Space for Humanity. Available online: http://www.ecologyandsociety.org/vol14/iss2/art32/ (accessed on 13 April 2020).

4. Madakufamba, M. (Rio+20) outcome document "The future we want.". In Proceedings of the Post Rio+20 Meeting of Civil Society and Trade Unions in Africa, Nairobi, Kenya, 19-20 November 2012; Available online: https://wedocs.unep.org/handle/20.500.11822/13934 (accessed on 5 February 2020).

5. FAO. The Ecosystem Approach to Fisheries; Fisheries Technical Paper 443; FAO: Rome, Italy, 2003.

6. Bené, C. When Fishery rhymes with Poverty: a first Step beyond the old Paradigm on Poverty in Small Scale Fisheries. World Dev. 2003, 31, 949-975. [CrossRef]

7. Jentoft, S.; Chuenpagdee, R. The Quest for Transdisciplinarity in Small-Scale Fisheries Governance. In Transdisciplinarity for Small-Scale Fisheries Governance; Springer Nature: Cham, Switzerland, 2019.

8. Spanish Business Confederation of Social Economy (CEPES). The Contribution of the Spanish Social Economy to the SDGs. IV Report on the Experience of Social Economy Companies in Development Cooperation 2017-2019. Available online: https://www.cepes.es/noticias/596_social-economy-central-actor-2030-agendaunited-nations-contributing-sustainable-development-goals\&lng=en (accessed on 21 May 2020).

9. CIRIEC. Manual Para la Elaboración de las Cuentas Satélite de las Empresas de Economía Social: Cooperativas y Mutuas from 2006. Available online: http://www.ciriec.uliege.be/wp-content/uploads/2015/12/ManualSatellite-AccountsESP_2006.pdf (accessed on 17 October 2019).

10. UNRISD. Social and Solidarity Economy and the Challenge of Sustainable Development; UNTFSSEUN Inter-Agency Task Force on Social and Solidarity Economy: Geneva, Switzerland, 2014; Available online: http://unsse.org/ wpcontent/uploads/2014/08/Position-Paper_TFSSE_Eng1.pdf (accessed on 22 January 2020).

11. Lee, S. Role of social and solidarity economy in localizing the sustainable development goals. Int. J. Sustain. Dev. World Ecol. 2020, 27, 65-71. [CrossRef]

12. Mozas, A. Contribución de las Cooperativas Agrarias al Cumplimiento de los Objetivos de Desarrollo Sostenible. Especial Referencia al Sector Oleícola 2019; Ciriec-España: Valencia, Spain, 2019.

13. The FAO Code of Conduct for Responsible Fisheries. Available online: http://www.fao.org/3/v9878e/v9878e00. htm (accessed on 12 September 2019).

14. Voluntary Guidelines for Securing Sustainable Small-Scale Fisheries in the Context of Food Security and Poverty Eradication. Available online: http://www.fao.org/3/i4356en/I4356EN.pdf (accessed on 21 May 2020).

15. Weeks, P. Fish and People: Aquaculture and the Social Sciences. Soc. Nat. Resour. 1992, 5, 345-357. [CrossRef]

16. FAO. Fishers' Knowledge and the Ecosystem Approach to Fisheries; Technical Paper 591; FAO: Rome, Italy, 2015.

17. Lam, M.E.; Pauly, D. Who is right to fish? Evolving a social contract for ethical fisheries. Ecol. Soc. $2010,3$. [CrossRef]

18. Cornforth, M. Philosophy for Socialists; Lawrence and Wishart: London, UK, 1959.

19. Chuenpagdee, R.P.; Jentoft, S. Transdisciplinarity for Small-Scale Fisheries Governance Analysis and Practice; Springer Nature: Cham, Switzerland, 2019; ISBN 978-3-319-94938-3.

20. Mc Leod, K.; Leslie, H. Ecosystem Based Management of the Oceans; Island Press: Washington, DC, USA, 2012. 
21. Weimer, D.L. Definitions of public policy analysis: Resources for promoting objectivity and balance in consolidated democracies. Policy Stud. J. 2005, 33, 131-146. [CrossRef]

22. Vaillancourt, Y. Social economy in the co-construction of public policy. Ann. Public Coop. Econ. 2009, 80, 275-313. [CrossRef]

23. UN Declaration on the Rights of Indigenous Peoples (UN DRIP). Available online: https://www.un. org/development/desa/indigenouspeoples/wp-content/uploads/sites/19/2018/11/UNDRIP_E_web.pdf. (accessed on 3 January 2020).

24. Douvere, F.; Ehler, C. An international perspective on marine spatial planning initiatives. Environments 2010, 37, 9-21.

25. FAO. The State of World Fisheries and Aquaculture: Meeting the Sustainable Development Goals; FAO: Rome, Italy, 2018.

26. Gallizioli, G. The social dimensions of the common fisheries policy: A review of current measures. In Social Issues in Sustainable Fisheries Management; Springer: Dordrecht, The Netherlands, 2014.

27. Linke, S.; Bruckmeier, K. Co-management in fisheries-Experiences and changing approaches in Europe. Ocean Coast. Manag. 2015, 104, 170-181. [CrossRef]

28. Kyvelou, S.S.I.; Ierapetritis, D.G. Fisheries Sustainability through soft multi-use maritime spatial planning and local development co-management: Potentials and challenges in Greece. Sustainability 2020, 12, 2026. [CrossRef]

(C) 2020 by the author. Licensee MDPI, Basel, Switzerland. This article is an open access article distributed under the terms and conditions of the Creative Commons Attribution (CC BY) license (http://creativecommons.org/licenses/by/4.0/). 